\title{
40. APTYCHI (AMMONOIDEA) FROM THE EARLY CRETACEOUS OF THE BLAKE-BAHAMA BASIN, LEG 44, HOLE 391C, DSDP
}

\author{
Otto Renz, Museum of Natural History, Basel, Switzerland
}

\section{INTRODUCTION}

Hole $391 \mathrm{C}\left(28^{\circ} 13.61^{\prime} \mathrm{N}, 75^{\circ} 37.00^{\prime} \mathrm{W}\right)$ drilled during Leg 44 is located just east of the Blake Plateau east of the Blake Escarpment in the Blake-Bahama Basin, which is separated from the Hatteras Abyssal Plain by the Blake-Bahama Outer Ridge. The water depth at the location is 4963 meters, and the hole penetrated 1412 meters of sediment.

A.W.Gorody (DSDP East Coast Repository at Lamont-Doherty Geological Observatory of Columbia University, Palisades, New York) collected 21 samples, of which 17 contained aptychi, two remains of ammonites, and one a rhyncholite. The material was received at the Museum of Natural History in Basel during April 1976.

The prime objective at the present stage of investigations on aptychi is to attempt correlations between holes. Hole 391C continuously cored section covering Late Jurassic and Early Cretaceous providing an opportunity to establish some correlation lines on the basis of aptychi from the Blake-Bahama Basin to Hole 387 of Leg 43 on the western Bermuda Rise, and to Hole 367 of Leg 41 on the Cape Verde Basin (Figure 1).

Fourteen species of aptychi suggesting an Early Cretaceous age, a rhyncholite of presumably Oxfordian age, and a few remains of ammonites were recovered from Hole $391 \mathrm{C}$ from an interval of 207 meters. New aspects regarding the stratigraphic position of single species, and information regarding the vertical distribution of groups of aptychi consisting of related species resulted from the new material (Figure 2). Of interest are indications of possible phylogenetic connections within certain groups of aptychi, as for instance the Lamellaptychus mortilleti group from the Berriasian present in the Holes 387 and 391C (Figure 3).

\section{AGE OF THE APTYCHUS ASSEMBLAGES FROM HOLE 391C (FIGURE 2)}

\section{Late Jurassic}

The deepest sample available from Hole 391C consists of a white, chalky limestone (Sample 44-6, 29$30 \mathrm{~cm}$ ) containing abundant radiolarians and a rhyncholite comparable to Palaeoteuthis honoratianus d'Orbigny, 1850. According to a recent publication on rhyncholites by Dieni $(1975$, p. 61 , pl. 2 , fig. 5-8) the genus Palaeoteuthis seems to indicate an Oxfordian age. A sediment column of 75 meters, from which no larger fossils are available, separates this specimen from the next younger sample containing Lamellaptychus transitorius n. sp. (Plate 1, Figure 1a,b). This interval would then represent the Kimmeridgian and the Tithonian.

\section{Early Cretaceous}

From the continuously cored interval comprising Cores 14 to 36, three assemblages of aptychi, separated by intervals of considerable thicknesses without samples, were available. The aptychus assemblages range in age from Berriasian to Hauterivian. The oldest fauna was extracted from a sediment column of 45 meters, corresponding to Cores 31 to 36 . Eight species of aptychi were isolated, from which only Lamellaptychus mortilleti (Pictet and Loriol) and L. aplanatus Trauth represent well-known forms. The remaining six new specimens are first described here. The two species indicate a Berriasian age (Pictet and Loriol, 1858; Trauth, 1938, p. 147; Gasiorowski, 1962, pl. 7).

The next younger assemblage of aptychi comes from an interval comprising Cores 24-28, which are separated from the previous cores by 20 meters of unsampled sediment. Six samples were available which furnished four species, two of which are new. Among the known species, this is the first recorded occurrence of Lamellaptychus excavatus from the Atlantic. The second known species, L. seranonis is represented by three specimens from Cores 24 and 25 . This form was found associated with Lamellaptychus didayi in Site 367 of Leg 41, where it was placed within the Valanginian stage (compare Gasiorowski, 1962, pl. 1, p. 22).

The latest assemblage is dominated by forms related to the Lamellaptychus angulocostatus group assumed to be of Hauterivian age. It is separated from the interval assigned to the Valanginian by an unsampled sediment column reaching the considerable thickness of 54 meters (Cores 18-23).

\section{CORRELATIONS OF EARLY CRETACEOUS DEPOSITS FROM THE WESTERN ATLANTIC (HOLE 391C) TO THE EASTERN ATLANTIC (SITE 367) (FIGURE 1)}

Aptychus assemblages have so far been examined from four sites in the northern Atlantic. On the basis of stratigraphic distribution of aptychi during Late Jurassic and Early Cretaceous, we are now able to propose some reliable correlation lines between the Blake-Bahama Basin (Hole 391C), the western Bermuda Rise (Site 387), and the Cape Verde Basin 


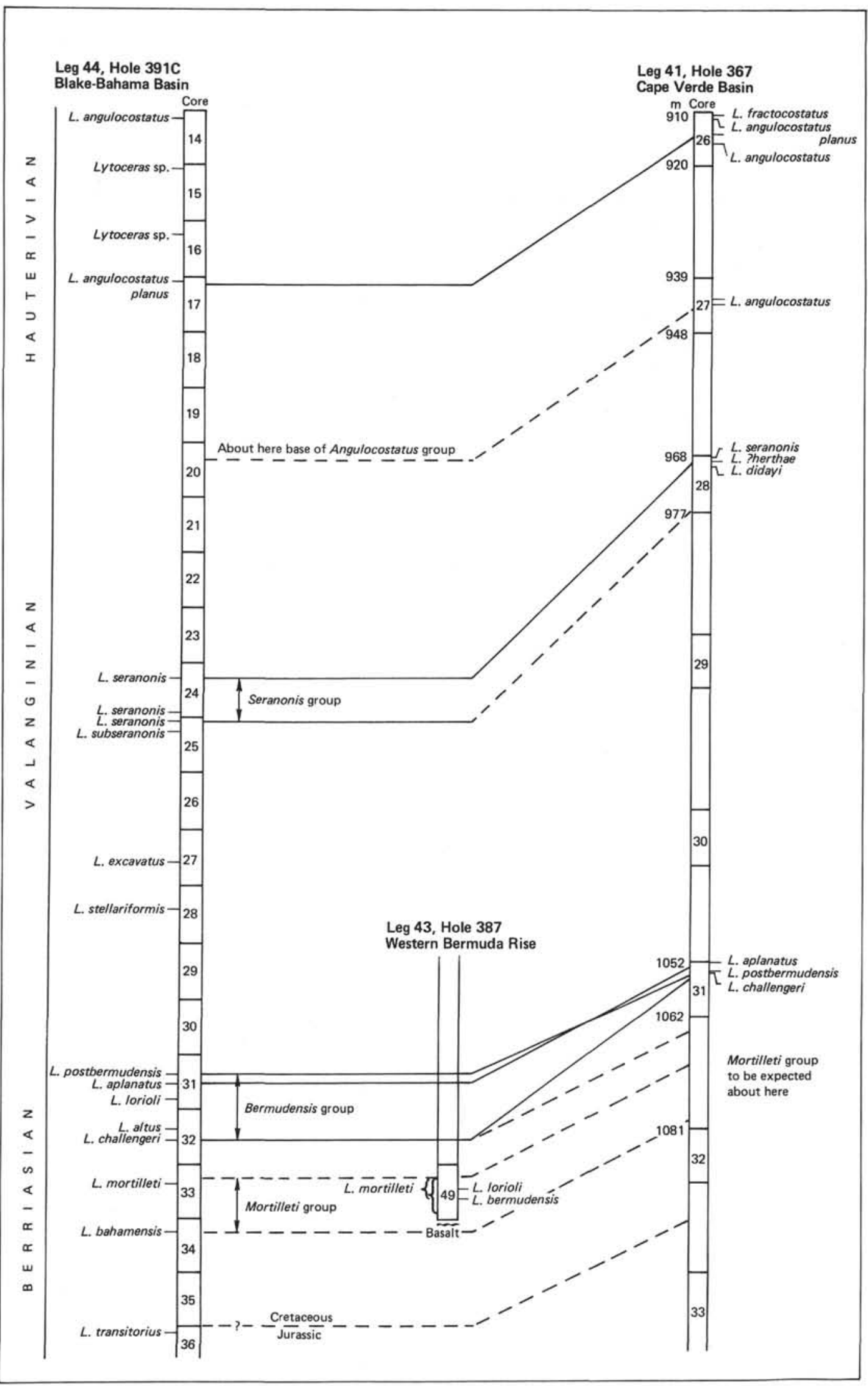

Figure 1. Distribution chart of aptychi from Leg 44, Site 391. 


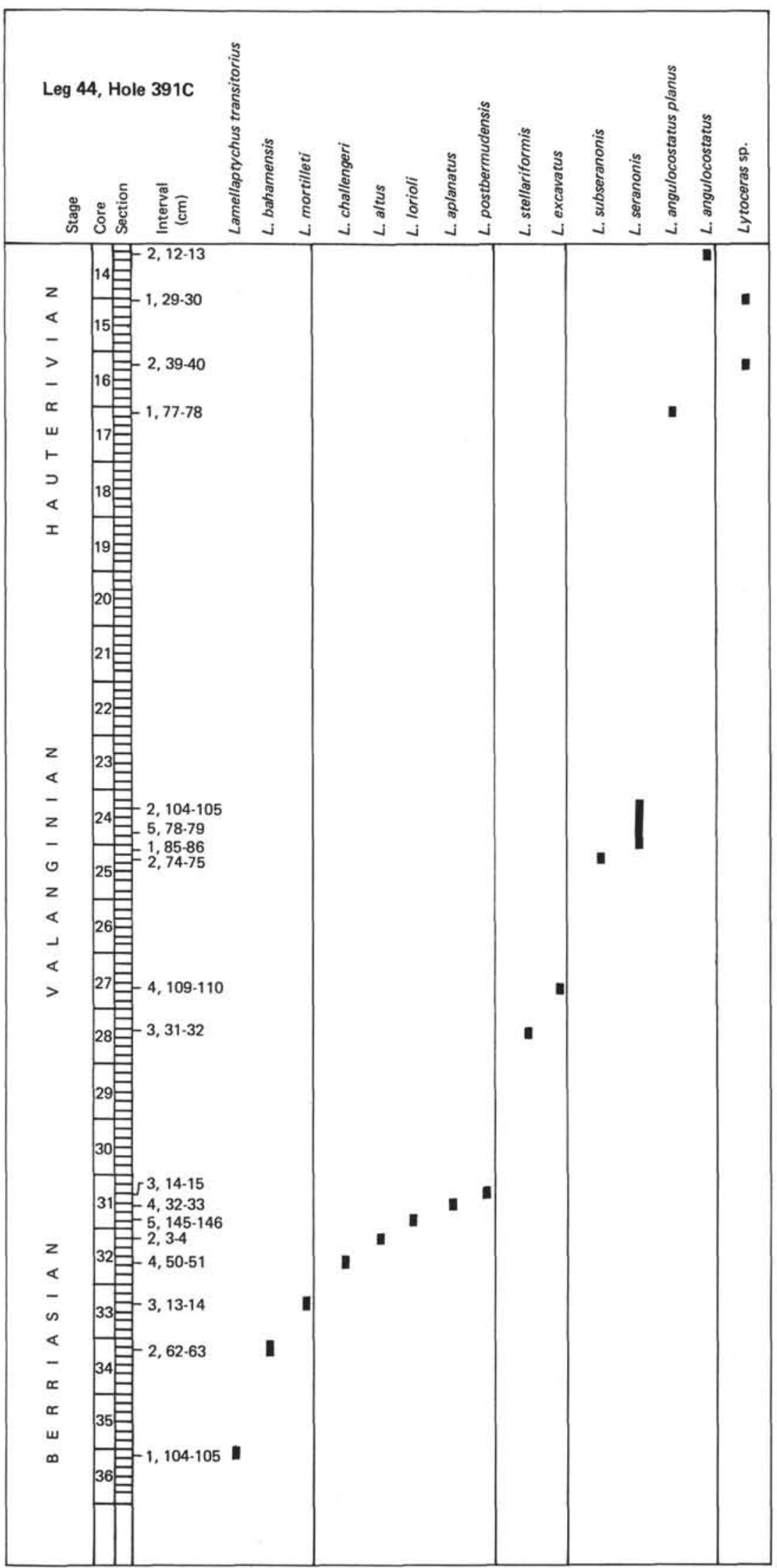

Figure 2. Attempted correlations based on aptychi between Leg 44, Site 391 (Blake-Bahama Basin), Leg 43, Site 387 (Bermuda Rise), and Leg 41, Site 367 (Cape Verde Basin). 

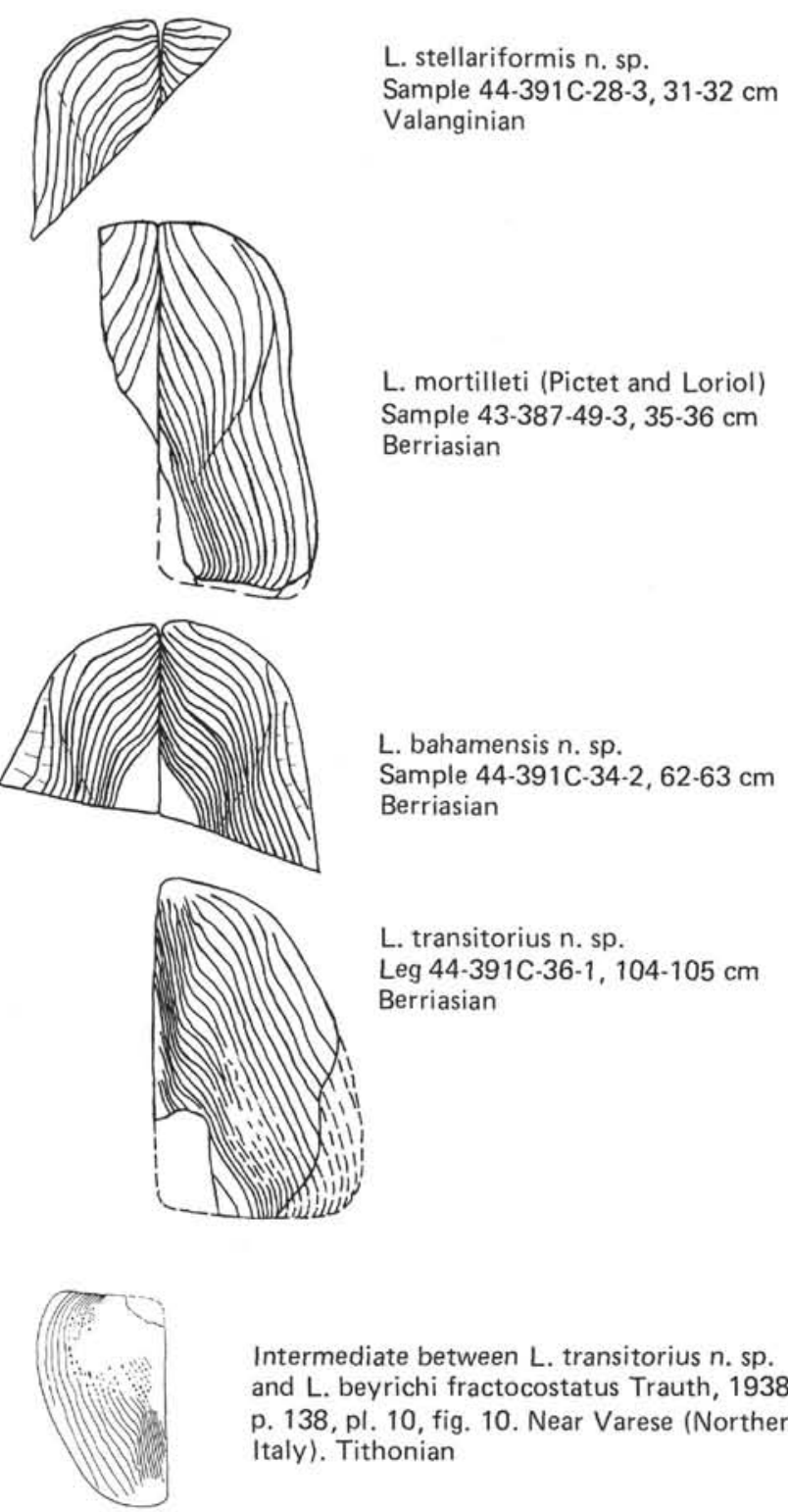

Intermediate between L. transitorius $\mathrm{n} . \mathrm{sp}$. and L. beyrichi fractocostatus Trauth, 1938, p. 138 , pl. 10, fig. 10. Near Varese (Northern Italy). Tithonian

Figure 3. Tentative phyllogenetic connections of aptychi from the Lamellaptychus mortilleti group.

(Site 367). So far correlations are restricted to intervals within the Early Cretaceous (Berriasian, Valanginian, and Hauterivian). The material available from the Late Jurassic is still too incomplete to allow correlations.

A total of 62 samples yielding 38 species of aptychi were studied from the early Cretaceous sediments. Their distribution in the four holes is as follows:

Hole 105, Hatteras Abyssal Plain: 8 samples, 5 species

Hole 367, Cape Verde Basin: 16 samples, 15 species Hole 387, Bermuda Rise: 19 samples, 16 species Hole 391C, Blake-Bahama Basin: 19 samples, 15 species

Among the 38 species obtained from the early Cretaceous sediments, six (representing 15\% of the total) occur in at least two of the four holes investigated; these six species enable us to establish firm correlations between the holes. They are from bottom to top: Lamellaptychus mortilleti, L. aplanatus, L. subbermudensis, ? L. lorioli, L. seranonis, and L. angulocostatus planus. Due to the scarcity of individuals, evidence of faunal affinities between the holes are as yet difficult to recognize.

On the correlation chart (Figure 1) solid lines connect the levels of common species occurring in two of the three holes. The stratigraphic range of single species is not yet adequately known to resolve zonal subdivision. Therefore, broken lines connect the top and bottom boundaries of certain groups of aptychi consisting of several related forms with common morphological features, and which are distributed within a certain interval.

Comparing Hole 367 with Hole $391 \mathrm{C}$ we note that sediment thicknesses of the intervals delimited by correlation lines are remarkably similar. We may assume that sedimentation rates throughout the intervals were constant at the two sites. On the basis of this assumption, we attempted to project the interval corresponding to the mortilleti group on the Bermuda Rise to Hole 367 in the Cape Verde Basin, where it would then fall within the uncored interval of about 20 meters thickness between Cores 31 and 32. The assumed Jurassic-Cretaceous boundary accordingly should pass within or below Core 32, and not near the top of Core 31 as supposed by the author in the report on aptychi from Site 367 , which was prepared before the existence of the mortilleti group in the Atlantic was known.

\section{CORRELATIONS WITHIN THE JURASSIC}

From the Late Jurassic only 20 samples have been examined from the northern Atlantic. Twenty species were obtained which are distributed as follows:

Hole 105, northern Hatteras Abyssal Plain: 10 samples, 10 species

Hole 367, Cape Verde Basin: 10 samples, 11 species.

In Hole 105 the aptychi are scattered over a rather long interval of 45 meters, between Cores 33 and 37 $(558-603 \mathrm{~m})$. Core 37 furnished a Laevaptychus latus (Parkinson) and the rhyncholite Leptocheilus acutus (Quenstedt, 1849) determined by Dieni (1975, pl. 67, fig. 23, p. 102). It indicates, according to Dieni, an Oxfordian age. The aptychi obtained from Cores 33 to 36 are not adequate for a reliable distinction between Kimmeridgian and Tithonian. The thickness of the Late Jurassic cannot be determined using aptychi, because of the lack of samples from the interval of 137 meters between Cores 18 and 33 (421-558 m).

Much better material was obtained from the Late Jurassic of Hole 367. Here two assemblages, recovered from nine samples, yielded 11 species. The deeper assemblage represents the Oxfordian, whereas the higher one seems to be Kimmeridgian in age. Aptychi indicating undoubted Tithonian have not been found. With the exception of the long-ranging Punctaptychus punctatus Voltz, no Late Jurassic species common to the two holes were isolated. The evidence for correlation is therefore lacking. 


\section{CONCLUSIONS}

The correlations between sites situated in the western and eastern North Atlantic based on ammonite opercula suggest that these fossils are equally valuable for regional correlations as their corresponding ammonites. They represent an alternative to pelagic foraminifers, which generally are poorly preserved in environments where aptychus valves are less affected by diagenetic alterations. The results obtained so far indicate that additional study or supplementary material, especially from the western Bermuda Rise (Hole 387, Leg 43) would considerably improve our present understanding. We suggest careful sampling of the continuously cored Valanginian-Hauterivian limestone section (between 600 and $800 \mathrm{~m}$ ). The importance of such an examination is further emphasized in Figure 1.

\section{SYSTEMATICAL DESCRIPTIONS}

Our knowledge on the stratigraphic ranges of species of aptychi is not sufficiently advanced to permit the establishment of "aptychi Zones." The designation "Zone" is therefore here replaced by "aptychi-group," meaning the vertical distribution of several closely related species of aptychi occurring within a certain delimited interval. The expressions assemblage or fauna are restricted to different unrelated species of aptychi present within a certain interval.

\section{Berriasian}

The lithology of most of the samples from Hole 391C, Cores 31 to 36 , assumed to be Berriasian age, consists predominantly of laminated, light gray, porous, chalky limestone. Within this interval three groups of aptychi are distinguished:

1) The mortilleti group composed of,

Lamellaptychus transitorius n.sp., Plate 1, Figure la-b

Lamellaptychus bahamensis n.sp., Plate 1, Figure 2

Lamellaptychus mortilleti (Pictet and Loriol), Plate 1, Figure $3 a-b$

2) The bermudensis group composed of,

Lamellaptychus challengeri n.sp., Plate 1, Figure 4a-b

Lamellaptychus altus n.sp., Plate 1, Figure 5a-d

Lamellaptychus postbermudensis n.sp., Plate 1, Figure 8a-b

3) The aplanatus group composed of,

Lamellaptychus lorioli Renz, Plate 1, Figure 6a-b

Lamellaptychus aplanatus (Gilliéron), Plate 1, Figure 7

The interval of Cores 33 and 34, containing forms belonging to the mortilleti group, might correspond to Core 49 of Hole 387 on the Bermuda Rise. Cores 31 and 32 , with species indicating the bermudensis group as well as the aplanatus group, can be correlated with Core 31 of Hole 367 in the Cape Verde Basin (see Figure 1).

\section{Lamellaptychus transitorius n.sp}

(Plate 1, Figure 1a-b)

Hole 391C, Sample 36-1, 104-105 cm, holotype, J 28195.

So far Lamellaptychus transitorius represents the lowest occurrence of an aptychus in this hole. It is separated by 70 meters of sediment from a rhyncholite (Palaeoteuthis cf. honoratianus d'Orbigny, Plate 1, Figure 18a-c) indicating an Oxfordian age (Dieni, 1975 , p. 61). The new name "transitorius"chosen for this form refers to its assumed stratigraphic position within the transition zone from Jurassic to Cretaceous.

The most characteristic feature of this species is the conspicuously obtuse angled bends of the lamellae. This consecutive bending takes place along a radial line running from the apex to the ventral margin of the valve. The furrows separating the lamellae are concomitantly more closely spaced, and the lamellae reach the symphysal edge along parallel, densely placed lines, meeting the symphysis with acute angles of about $10^{\circ}$. In the vicinity of the most elevated region of the valve a thin layer of calcite coats its surface, leaving free only narrow elongated splits, and rounded pores, which are placed along the furrows separating the lamellae underneath. The width/length ratio $=$ width index reaches 0.60 .
A closely related specimen (J 28214) from the Maiolica-facies of Tithonian age near Varese in northern Italy, collected by $\mathrm{O}$. Kälin of the Geological Institute in Basel, has the same width index. The morphological features of this valve are almost identical to those observed on L. transitorius. The calcite coating over the highest elevated region of this valve is, however, considerably more extensive, partly due to the larger size of the valve. In addition the conspicuous bending of the lamellae is still more distinct than on the present specimen from the Blake-Bahama Basin.

On the basis of its morphology this species might be an ancestor of Lamellaptychus mortilleti. This is suggested by Figure 3, which shows a possible phylogenetic sequence of aptychi forming the mortilleti group.

\section{Lamellaptychus bahamensis n.sp.}

$$
\text { (Plate 1, Figure 2) }
$$

Hole 391C, Sample 34-2, 62-63 cm, holotype, J 28196.

This species occurs above Lamellaptychus transitorius, and is separated from it by about 17 meters of sediment. L. bahamensis combines characteristic features of L. transitorius and Lamellaptychus mortilleti (Pictet and Loriol). the later occurs 7.15 meters higher in this hole.

The dorsal half of this pair of valves was cut off. A rounded keel (or elevation) beginning near the junction between lateral and ventral margin crosses the valve diagonally. On its marginal side it is followed by a weak depression connected with a sigmoidal bending of the lamellae. Towards the symphysal edge the lamellae bend, consecutively along a radial line towards the symphysis, which they follow in direction of the ventral end of the valve. This bending is less pronounced than in L. transitorius. The lamellae parallel the ventral margin of the valve, and converge towards its ventral end as on Lamellaptychus oceanicus Renz from the Bermuda Rise (Leg 43, Sample 387-49-5, 2-3 cm, Plate 1, Figure 11a-b).

\section{Lamellaptychus mortilleti (Pictet and Loriol)}

(Plate 1, Figure 3a-b)

1858 Aptychus Mortilleti Pict. and Lor., p. 50, fig. 9 (lectotype). 1977b Lamellaptychus mortilleti (Pict. and Lor.), Renz, Site 387 (Bermuda Rise), pl. 1, fig. 17-22, Renz, 1977b.

Hole 391C, Sample 33-3, 13-14 cm, J 28197.

A single right valve, which was cut along its symphysal border was found. A reconstruction of the missing part showing the bending of the lamellae towards the symphysal edge has been attempted (Plate 1, Figure $3 \mathrm{~b}$ ). This significant specimen permits a correlation with Core 49 of Hole 387 on the Bermuda Rise, where L. mortilleti occurs abundantly.

\section{Lamellaptychus challengeri n.sp. (Plate 1, Figure 4a-b)}

1977a Lamellaptychus indet. 2, Renz, Site 367 (Cape Verde Basin), pl. 1, fig. 24a-c, in press.

Holotype: Lamellaptychus indet. 2, Renz 1977a, Cape Verde Basin, 367-31-2, 4-5 cm, Plate 1, Figure 24a-c, J 28218. Hole 391C, Sample 32-4, 50-51 cm, J 28198.

The partially preserved pair of valves corresponds to a specimen from the Cape Verde (Leg 41, Sample 367-31-2, 2-5 cm, Plate 1, Figure $24 \mathrm{a}-\mathrm{c}$ ), which was previously designated as Lamellaptychus indet. 2. Owing to its importance for a correlation between the two holes I designate it here by the new name Lamellaptychus challengeri. The species is characterized by a prominent high, ridge-like keel, over which the lamellae are effaced. The keel falls off vertically towards the lateral margin of the valve, and rather gently towards it symphysal edge. Along the steep slope of the keel the lamellae are bent in indistinct acute-angled inflections. They meet the symphysal edge at right angles.

The morphological features of $\mathrm{L}$. challengeri suggest a close relation with Lamellaptychus bermudensis from the Bermuda Rise (Sample 387-49-4, 104-105 cm, Plate 1, Figure 2). This species also has a pronounced keel which interrupts the lamellae. However, it slopes off steeply towards both sides. The lamellae pattern is comparable to that of L. challengeri. Both species form part of the bermudensis group, which according to our present views, indicates a Berriasian age. 


\section{Lamellaptychus altus n.sp.}

(Plate 1, Figure 5a-d)

Hole 391C, Sample 32-2, 3-4 cm, holotype, J 28199.

About 3.5 meters above the level, which furnished Lamellaptychus challengeri, a small Lamellaptychus having uncommon morphological features was found. The ventral end of this pair of valves has been cut off and had to be reconstructed (Figure 5c). An extremely high and acutely crested keel dominates the morphology of this species. As far as exposed, on the better preserved right valve, this keel begins just above the junction between the ventral and lateral margins. It rises steeply, and extends diagonally over the middle sector of the valve. Close to the symphysis it turns in direction of the apex, paralleling the symphysis. The slope from the crest of the keel towards the lateral margin is steep (about $43^{\circ}$ ). Towards the symphysal side of the valve the keel falls off vertically. Between the base of the vertical slope and the symphysis the valve is flat (horizontal) as shown by the cross-section, Figure $5 \mathrm{~d}$. Within this flat region the calcite composing the valve seems to be partially replaced by a black, very fragile coaly substance.

Figure $5 \mathrm{~b}$ is an oblique view showing the surface of the slope between the keel and the lateral margin of the right valve. The keel clearly turns into a direction parallel to the symphysis. On the left valve the crest of the keel and the face of its vertical slope are exposed.

This species combines, in an exaggerated way, the significant features characterizing all the members of the bermudensis group.

\section{Lamellaptychus lorioli Renz}

(Plate 1, Figure 6a-b)

1867 Aptychus Seranonis Coquand, Pictet, p. 123, pl. 28, fig. 9b. 1938 Lamellaptychus seranonis (Coquand), Trauth, p. 193, pl. 13, fig. 29.

1977b Lamellaptychus lorioli Renz, pl. 1, fig. 5a-b; Leg 43, Site 387, Bermuda Rise, in press.

Holotype: Lamellaptychus lorioli Renz from the Bermuda Rise, Sample 43-387-49-3, 103-104 cm, Plate 1, fig. 5a-b, J 28219.

Hole 391C, Sample 31-5, 145-146 cm, J 28200.

This juvenile, broadly arched left valve, has the beginning of backward curved lamellae. Its width/length ratio $=$ width index, after reconstruction, reaches 0.40 compared with 0.42 of the specimen figured by Pictet (1867), and 0.52 for the holotype from the Bermuda Rise.

On the Bermuda Rise (Hole 387) this species from Core 49, would according to our present correlation (Figure 2) correspond to Core 33 of Hole 391C. Disregarding differences in sedimentation rates between the two holes, a vertical range of about 15 meters results for L. lorioli.

\section{Lamellaptychus aplanatus (Gilliéron)}

$$
\text { (Plate 1, Figure 7) }
$$

1938 Lamellaptychus aplanatus (Gilliéron), Trauth, p. 171, pl. 12, fig. 8-10.

1977a Lamellaptychus aplanatus (Gilliéron), Renz, pl. 1, fig. 25a-b, Site 367, Cape Verde Basin.

Hole 391C, Sample 31-4, 32-33 cm, J 28201.

The ventral end of a left valve compares satisfactorily with $L$. aplanatus (Gilliéron). The thin-shelled fragment with flat-lying lamellae is moderately broadly arched, thus not flattened by compaction as are the specimens found in Core 31 in the Cape Verde Basin.

\section{Lamellaptychus postbermudensis n.sp.} (Plate 1, Figure 8a-b)

1977a Lamellaptychus indet. 1, Renz, pl. 1, fig. 23a-b, in press. Hole 391C, Sample 31-3, 14-15 cm, holotype, J 28202.

The morphological features characterizing this small left valve are very similar to those on an equally small pair of valves described from the Cape Verde Basin. This specimen has been provisionally labeled "Lamellaptychus indet. 1." The ventral half of the valve is entirely preserved; the lateral margin of its dorsal half is missing, and had to be reconstructed (Plate 1, Figure 8b). Its outstanding keel extends diagonally over the middle sector of the valve, and flattens before reaching the apex. The lamellae are not inflected over the keel. Width/length ratio $=$ width index 0.46 , compared with 0.50 for the specimen from the Cape Verde Basin.

\section{Valanginian}

Because of large unsampled intervals between the Berriasian and Valanginian, little is known about the boundary between these two stages in the holes examined for aptychi (Figure 1). The interval representing the Valanginian comprises Cores 24 to 28 . The samples consist of uniform, laminated, grayish, porous, chalky limestone with calcified radiolarians. The sequence is lithologically comparable to that below of Berriasian age.

The assemblage consists of seven aptychi representing five species. The age-indicating Lamellaptychus seranonis (Coquand) was found in Cores 24 and 25 in the upper part of the interval. L. seranonis is represented by three individuals from different levels. Cores 24 and 25 can therefore be correlated with Core 28 of Hole 367 in the Cape Verde Basin (Figure 1).

\section{Lamellaptychus stellariformis n. sp.}

(Plate 1, Figure 9; Text-Figure 3)

Hole 391C, Sample 28-3, 31-32 cm, holotype, J 28203.

This interesting pair of valves has unfortunately been cut diagonally. It has features in common with Lamellaptychus ambiguus Renz, 1977b, from the Bermuda Rise (Hole 387, Core 49; pl. 1, fig. 13a-b, 14).

A broadly arched elevation beginning between the ventral and lateral margins seems to extend diagonally over the valve like in L. mortilleti. The older exposed lamellae bend sigmoidally as they approach the symphysis, which they follow towards the ventral end or the valve, as is the case in L. mortilleti. The last formed three lamellae show a similar sudden change in direction when approaching the symphysis as occurs in L. ambiguus. Instead of following the symphysal edge in sigmoidal bends, the lamellae meet the symphysis at right angles. Within a short distance they change from a sigmoidal shape near the symphysis to a rectangular one. On the basis of our correlations (Figure 1) L. ambiguus occurs considerably lower in the section than L. stellariformis.

\section{Lamellaptychus excavatus Trauth \\ (Plate 1, Figure 10a-b)}

1857 Trigonellites Studeri Ooster, p. 26-28, pl. 7, fig. 2 (holotype). 1858 Aptychus Seranonis Coquand, Pictet and Loriol, p. 48, pl. 11, fig. 3 .

1938 Lamellaptychus excavatus Trauth, p. 178, pl. 12, fig. 20, 21.

1942 Lamellaptychus excavatus Trauth, Imlay, p. 1461, pl. 11, fig. 1, 5 .

1962 Lamellaptychus excavatus Trauth, Gasiorowski, pl. 7, fig. 9.

Hole 391C, Sample 27-4, 109-110 cm, J 28204.

L. excavatus is characterized by a rounded elevation crossing the valve diagonally. Its slope against the symphysis is steeper than that towards the lateral margin. The elevation is followed by a shallow depression of the valve, across which the latest (marginal) lamellae are weakly bent. The lamellae meet the symphysis at angles of about $60^{\circ}$, rather like in Lamellaptychus herthae (Winkler). The last ones end against the ventral margin of the valve. Width/length ratio 0.56 , compared with 0.54 on the holotype.

L. excavatu- is known from the Neocomian near Beatenberg in the Canton of Berne, Switzerland (Ooster, 1857), as well as from the Neocomian of Hivernage east of Geneva in France (Pictet and Loriol, 1858). Imlay described well preserved examples from the Viñales Limestone in Cuba. Gasiorowski (1962) listed tbis form from the Carpathians within horizon 7 corresponding to the Berriasian.

\section{Lamellaptychus ef. herthae (Winkler)}

(Plate 1, Figure 11a-b)

Hole 391C, Core 27-4, 109-110 cm, J 28205.

This juvenile specimen is probably referable to the group of Lamellaptychus herthae (Winkler). Similarly small specimens from Samples 28-2, 66-67 cm and 60-61 cm from Site 367 in the Cape Verde Basin (Renz, pl. 1, fig. 31-33) have more prominent keels and more inflected lamellae. For a better understanding of those small specimens additional material is required.

\section{Lamellaptychus subseranonis $\mathbf{n}$. sp.}

(Plate 1, Figure 12)

Hole 391C, Sample 25-2, 74-75 cm holotype, J 28206.

This pair of valves is separated from Lamellaptychus excavatus Trauth by 21.35 meters of sediment without aptychi. L. subseranonis 
is considered to be related to Lamellaptychus seranonis (Coquand), and possibly represents an ancestral form of that species. The right valve slightly overlaps the symphysal edge of the left valve, partly covering the retroverse turning of the lamellae. The species differs from L. seranonis by a less pronounced retroverse bending of the lamellae, which sets in at a later stage as in L. seranonis. The valve is crossed diagonally by a broadly arched elevation sloping about equally steep to both sides. The lamellae are closely spaced, not inflected, and run parallel to the lateral margin.

\section{Lamellaptychus seranonis (Coquand)}

(Plate 1, Figures 13, 15)

1938 Lamellaptychus seranonis (Coquand), Trauth, p. 193, pl. 13, fig. 27-28.

1977a Lamellaptychus seranonis (Coquand), Renz, pl. 1, fig. 27-30, Cape Verde Basin.

Two specimens, and the subspecies L. seranonis fractocostatus Trauth, are present over an interval of 7.70 meters. In the Cape Verde Basin (Hole 367, Core 28) L. seranonis is well represented (Figure 1). Hole 391C, Sample 25-1, 85-86 cm, J 28207.

This fragment possesses a narrow symphysal plate similar to that observed on the specimen referred to as L. aff. seranonis from Hole 367 in the Cape Verde Basin (pl. 1, fig. 27).

Hole 391C, Sample 24-2, 104-105 cm, J 28208.

This pair of valves shows the features typical of L. seranonis: a well-developed rounded keel followed by a shallow depression, which is crossed by slightly inflected and backwards turning lamellae.

\section{Lamellaptychus seranonis fractocostatus Trauth} (Plate 1, Figure 14)

1938 Lamellaptychus seranonis var. fractocosta Trauth, p. 197.

1962 Lamellaptychus seranonis var. fractocosta Trauth, Gasiorowski, pl. 8, fig. 5 .

Hole 391C, Sample 24-5, $7879 \mathrm{~cm}$, J 28209.

This well-preserved pair of valves is distinguished by an outstanding keel and a well-developed depression of the valve. Within this depression the lamellae have narrowly bended inflections.

Trauth (1938) mentioned this subspecies from the Neocomian of the Bavarian Alps. It has been recorded from the Carpathians by Gasiorowski (1962) from horizon 8 (Valanginian-Hauterivian).

\section{Hauterivian}

The interval characterized by Lamellaptychus seranonis considered to represent the Valanginian is overlain by 65 meters of sediment without larger fossils (Cores 18-23). The corresponding interval in Hole 367 (Core 27) in the Cape Verde Basin (920 to $968 \mathrm{~m}$ ) (Figure 1) yielded two specimens belonging to the Lamellaptychus angulocostatus group. Accordingly, the Valanginian-Hauterivian boundary passes somewhere below this level.

Four samples obtained from the Cores 14 to 17 consist of a gray calcilutite, rich in terrigenous material, and abundant calcified radiolarians. They yielded two aptychi assigned to the group of $\mathrm{O}$. angulocostatus, and some remains of ammonites belonging to the Family Lytoceratidae.

\section{Lamellaptychus angulocostatus (Peters)}

(Plate 1, Figure 17)

1969 Lamellaptychus angulocostatus (Peters), Hoŭsa, p. 119, pl. 24, fig. 4.

1972 Lamellaptychus angulocostatus (Peters), Renz, p. 617, pl. 4, fig. 5. (Leg 11, Site 105).

Hole 391C, Sample 14-2, 12-13 cm, J 28210.

A well-preserved impression of this heteromorph form was found. A cast shows a broadly arched diagonal elevation followed by a very shallow depression of the valve, connected with a weak sigmoidally bending of the lamellae. The specimen is comparable to those exposed on a limestone slab figured by Hoŭsa $(1969$, pl. 24, fig. 4) from the Neocomian aptychus beds in Soroa, Province Pinar del Rio, Cuba.

\section{Lamellaptychus angulocostatus planus n. ssp.}

(Plate 1, Figure 16)

1977a Lamellaptychus angulocostatus (Peters), Renz, pl. 2, fig. 2, Cape Verde Basin, Site 367, in press.
Hole 391C, Sample 17-1, 77-78 cm, holotype, J 28211.

This subspecies is distinguished by the absence of a clear diagonal elevation as present in $\mathrm{L}$. angulocostatus described above. The valve is flatly arched, and the lamellae, as far as visible, are not inflected.

\section{Remains of ammonites}

Some poorly preserved ammonite remains were recovered from the upper part of the section investigated for aptychi, which is considered to represent the Hauterivian. All the fragments belong to the Subfamily Lytoceratinae, and apparently are related to the genus Lytoceras.

Lytoceras sp.

(Plate 1, Figure 20a-b)

Hole 391C, Sample 6-2, 39-40 cm, J 28212.

Shell fragments with riblets, and short segments of the suture are visible on the single specimen available.

\section{Lytoceras ? subfimbriata (d'Orbigny)}

(Plate 1, Figure 21)

Hole 391C, Sample 15-1, 29-30 cm J 28213.

Dr. F. Wiedenmayer (Museum of Natural History, Basel), a specialist for Lower Jurassic ammonites, was consulted for an identification of this impression. Comparing the impression with material from the Neocomian from Chattel-St.-Denis (Canton of Fribourg, Switzerland), we concluded that the impression represents a whorl fragment of a large Lytoceras subfimbriatum. For comparison, we here figure a whorl segment of this species from Châtel-St.-Denis (Plate 1, Figure 22, J 13124) showing the densely spaced, crinkled growth lines, and one of the periodical constrictions (indicated by arrows in the figures).

\section{Rhyncholites}

Four species of rhyncholites have been found thus far from holes drilled in the Atlantic:

Leg 11, Hole 105, Sample 37-5, 32-35 cm: Leptocheilus acutus (Quenstedt, 1849).

Leg 43, Hole 387, Sample 35, CC: Rhynchoteuthis (Rh.) escheri Ooster, 1859.

Leg 43, Hole 387, Sample 35, CC: Gonatocheilus expansus Till, 1907.

Leg 44, Hole 391C, Sample 44-6, 29-30 cm: Paleoteuthis cf. honoratianus d'Orbigny, 1850.

Leptocheilus acutus (Quenstedt)

1972 ? Zeugomatolepas, Renz, p. 609, pl. 4, fig. 8; Sample 11-105$37-5,32-35 \mathrm{~cm}$

1975 Leptocheilus acutus (Quenstedt), Dieni, p. 90, pl. 67, fig. $23 \mathrm{a}, 23 \mathrm{c}$

This rhyncholite (J 22607) was misinterpreted by O. Renz in 1972. For a detailed description reference is made to Dieni's monograph on rhyncholites (1975).

According to Dieni, 1975 (p. 102) L. acutus is abundant in the Oxfordian of France, Italy, Switzerland, Poland (Gasiorowski, 1973), and Spain (Geyssant, 1972).

\section{Gonatocheilus expansus Till}

(Plate 1, Figure 19a-b)

1975 Gonatocheilus expansus Till, Dieni, p. 77, pl. 62, fig. 5-22; pl. 65 , fig. 2 ; pl. 67, fig. 24.

1977a Gonatocheilus sp., Renz, pl. 2, fig. 10; Site 367, Cape Verde Basin. Leg 41, Hole 367, Sample 35, CC, J 28216.

This specimen was figured in the report on aptychi from the Cape Verde Basin (DSDP Vol. 41) before Dieni's monograph was available. Since then the ventral side of this specimen has been cleaned in order for it to be refigured here.

All features visible on this specimen are in close agreement with the extensive descriptions of this species by Dieni, 1975 (p. 84).

According to this author Gonatocheilus expansus is one of the most common species in the Oxfordian of Switzerland, Southern France, and Italy. 


\section{Rhynchoteuthis (Rhynnchoteuthis) escheri Ooster}

1975 Rhynchoteuthis (Rh.) escheri Ooster, Dieni, p. 52, pl. 62, fig. 1; pl. 67, fig. 26 (lectotype).

1977a Rhynchoteuthis sp., Renz, pl. 2, fig. 11 (Cape Verde Basin, Site 367 , Core $35-\mathrm{CC})$.

This small specimen (J 28217) was isolated from the sample, which yielded Gonatoheilus expansus Till. It closely resembles the lectotype from the Oxfordian of Sulzgraben (Canton of Berne, Switzerland). The species is also known from the Oxfordian of northern Italy (Belluno)

\section{Palaeoteuthis ef. honoratianus d'Orbigny} (Plate 1, Figure 18a-c)

1913 Palaeoteuthis Honoratianus d'Orb., Cottreau, pl. 9, fig. 1-3 (holotype).

1964 Palaeoteuthis honoratianus d'Orb., Teichert et al., K 478, fig. 344A.

1975 Palaeoteuthis honoratiana d'Orb., Dieni, p. 61, pl. 2, fig. 5-8. Hole 391C, Sample 44-6, 29-30 cm, J 28215.

About 75 meters below the level with Lamellaptychus transitorius a single rhyncholite was isolated from a white, chalky limestone rich in calcified radiolarians. The left lateral margin of the triangular hood has been cut off. It is strongly convex with a pronounced axial ridge sloping at about $45^{\circ}$ towards the lateral margins of the hood. The ventral surface is slightly concave and divided by a flatly rounded median elevation, which is uninterrupted from tip to base. A median furrow was not observed. The short shaft with a concavely depressed median area is pathologically distorted to the left.

The specimens investigated by Dieni are from the Oxfordian of France, Italy, and Switzerland.

\section{Conclusions}

The four species of rhyncholites found in the holes drilled in the Atlantic indicate an Oxfordian age for the corresponding sediments.

\section{ACKNOWLEDGMENTS}

I wish to thank Paula Worstell, scientist on board Glomar Challenger during Leg 44 of the Deep Sea Drilling Project, for arranging the sampling of the macrofauna from Hole 391C. The material was collected by A.W.Gorody (DSDP East Coast Repository, Lamont-Doherty Geological Observatory of Columbia University, Palisades, N.Y.). I am grateful to P. Jung, head of the Geological Department of the Museum, for reading the manuscript critically. I also acknowledge the photographical work done by W. Suter photographer of the museum.

\section{REFERENCES}

Coquand, M., 1841. Mémoire sur les Aptychus: Soc. géol. France Bull., v. 12, p. 376-391.

Dieni, I., 1975. Revisione di alcune spezie giurassiche e cretacee di rincoliti: Palaeontogr. Ital., v. 69, p. 38-107.

Gasiorowski, S.M., 1962. Aptychi from the Dogger, Malm and Neocomian in the Western Carpathians, and their stratigraphical value: Studia Geol. Polonica, v. 10, p. 1144.

Gasiorowski, S.M., 1973. Les Rhyncholites. Geobios, v. 6, p. 127-196.

Geyssant, J.R., 1972. La fauna de rhyncholites. In Geyssant, J.R. and Geyer, O.F. (Eds.), Rhyncholites du Jurassique superieur d'Espagne: Paläont. Z., v. 46, p. 151-179.

Gilliéron, V., 1873. Aperçu géologique sur les Alpes de Fribourg en général et description spéciale du Montsalvens: Mat. Carte géol. Suisse, v. 12, p. 1-273.

Hoŭsa, V., 1969. Neocomian rhyncholites from Cuba: $J$. Paleontol., v. 43, p. 119-124.

Imlay, R.W., 1942. Late Jurassic fossils from Cuba and their economic significance: Geol. Soc. Am. Bull., v. 53, p. $1417-1478$.

Ooster, W.A., 1859. Catalogue des céphalopodes fossiles des Alpes Suisses. II Céphalopodes d'order incertains: Nouv. Mém. Soc. Helv. Sci. Nat., v. 17, p. 1-32.

Pictet, F.J., 1867. Mélange paléontologiques. Etudes paléontologiques sur la faune a Terebratula diphyoides de Berrias (Ardèche): Mém. Soc. Phys. Hist. Nat. Genève, v. 17 , p. $43-130$.

Pictet, F.J. and Loriol, P., 1858. Description des fossiles contenus dans les terrains néocomiens des Voirons: Mat. paleont. Suisse, 2 sér., p. 1-64.

Quenstedt, F.A., 1849. Petrefactenkunde Deutschlands: Die Cephalopoden, $580 \mathrm{p}$.

Renz, O., 1972. Aptychi (Ammonoidea) from the Upper Jurassic and Lower Cretaceous of the western North Atlantic (Site 105, Leg 11, DSDP). In Hollister, C.D., Ewing, J.I., et al., Initial Reports of the Deep Sea Drilling Project, Volume 11: Washington (U.S. Government Printing Office), p. 607-629.

, 1978a. Aptychi (Ammonoidea) from the Late Jurassic and Early Cretaceous of the Eastern Atlantic, DSDP Site 367. In Lancelot, Y., Seibold, E., et al., Initial Reports of the Deep Sea Drilling Project, Volume 41: Washington (U.S. Government Printing Office), p. 499514.

, 1978b. Aptychi (Ammonoidea) from the Early Cretaceous of the western Bermuda Rise. Leg 43, Site 387. In Tucholke, B., Vogt, P., et al., Initial Reports of the Deep Sea Drilling Project, Volume 43: Washington (U.S. Government Printing Office).

Stefanov, J., 1961. Ammonoid Operculumns (Aptychi) from the Lower Cretaceous of Bulgaria: Trav. geol. Bulgarie, v. 3 , p. $210-235$.

Teichert, C., Moore, R.C., and Zeller, D.E.N., 1964. Rhyncholites. In Moore, R.C. (Ed.), Treatise on Invertebrate. Paleontology. K Mollusca 3, p. K 467-K 484.

Till, A., 1907. Die fossilen Cephalopodengebisse: Jb. Geol. Reichsanst., v. 57, p. 535-682.

Trauth, F., 1938. Die Lamellaptychi des Oberjura und der Unterkreide: Paleontographica, Abt. A, v. 88, p. 115-229. 



\section{PLATE 1}

Hole 391C, Cores 31-36, Berriasian

Figure 1a

Figure 1b

Figure 2

Figure 3a

Figure 3b

Figure 4a

Figure 4b

Figure 5a

Figure 5b

Figure 5c

Figure 5d

Figure 6a

Figure $6 \mathrm{~b}$

Figure 7

Figure 8a

Figure 8b

Figure 9

Figure 10a

Figure 10b

Figure 11a

Figure 11b

Figure 12

Figure 13

Figure 14

Figure 15

Figure 16

Figure 17

Figure 18a

Figure 18b

Figure 18c

Figure 19a

Figure 19b

Figure 20a

Figure 20b

Figure 21

Figure 22
Sample 36-1, 104-105 cm: Lamellaptychus transitorius n.sp., J 28195, $2.8 \times$.

Reconstruction. 2.5X.

Sample 34-2, 62-63 cm: Lamellaptychus bahamensis n.sp., J 28196, 2.5X.

Sample 33-3, 13-14 cm: Lamellaptychus mortilleti Pictet and Loriol, J 28197, 2.5×.

Reconstruction. $2.5 \times$.

Sample 32-4, 50-51 cm: Lamellaptychus challengeri n.sp., J 28198, $2.5 \times$.

Reconstruction. $2.5 \times$.

Sample 32-4, 50-51 cm: Lamellaptychus altus n.sp., J 28199, 5X.

Oblique view on the right valve showing the keel. The face of the vertical slope of the left valve is visible. $5 \times$.

Reconstruction. $5 \times$.

Cross-section of the valves. $5 \times$.

Sample 31-5, 145-146 cm: Lamellaptychus lorioli Renz, J 28200, $2 \times$.

Reconstruction. $2 \times$.

Sample 31-4, 32-33 cm: Lamellaptychus aplanatus (Gilliéron, J 28201, 2.5×).

Sample 31-2, 2-3 cm: Lamellaptychus postbermudensis n.sp., J 28202, 4X.

Reconstruction. $4 \times$.

\section{Hole 391C, Cores 24-28, Valanginian}

Sample 28-3, 31-32 cm: Lamellaptychus stellariformis n.sp., J 28203, $2.5 \times$.

Sample 27-4, 109-110 cm: Lamellaptychus excavatus Trauth, J 28204, 1.5×.

Reconstruction. $1.5 \times$.

Sample 27-4, 109-110 cm: Lamellaptychus cf. herthae (Winkler), J 28205, 4X.

Same specimen. $1.5 \times$.

Sample 25-2, 74-75 cm: Lamellaptychus subseranonis n.sp., J 28206, $4 \times$.

Sample 25-1, 85-86 cm: Lamellaptychus seranonis (Coquand), J 28207, 2.5×.

Sample 24-5, 78-79 cm: Lamellaptychus seranonis fractocostatus Trauth, J 28209, 1.5 .

Sample 24-2, 104-105 cm: Lamellaptychus seranonis (Coquand), J 28208, 2.5.

\section{Hole 391C, Cores 14-17, Hauterivian}

Sample 17-1, 77-78 cm: Lamellaptychus angulocostatus planus n.ssp., J 28211, $2 \times$.

Sample 14-2, 12-13 cm: Lamellaptychus angulocostatus (Peters), J 28210, 1.5 $\times$.

\section{Rhyncholites}

Leg 44, Sample 391C, 44-6, 29-30 cm: Palaeoteuthis cf. honoratianus d'Orbigny, J 28215, dorsal view, $2.5 \times$.

Ventral view. $2.5 \times$.

Lateral view, $2.5 \times$.

Leg 41, Sample 367, 35, CC: Gonatocheilus expansus Till, J 28216, dorsal view, 4X.

Ventral view. $4 \times$.

\section{Ammonites}

Sample 16-2, 39-40 cm: Lytoceras sp., J 28212, shell fragments, 1.5×.

Fragment of suture line, $2 \times$.

Sample 15-1, 29-30 cm: Lytoceras ? subfimbriatum (d'Orbigny), J 28213, $1 \times$.

Lytoceras subfimbriatum (d'Orbigny), J 13124, from the Neocomian of Châtel-St.-Denis (Canton Fribourg) Switzerland, 1X. 
PLATE 1
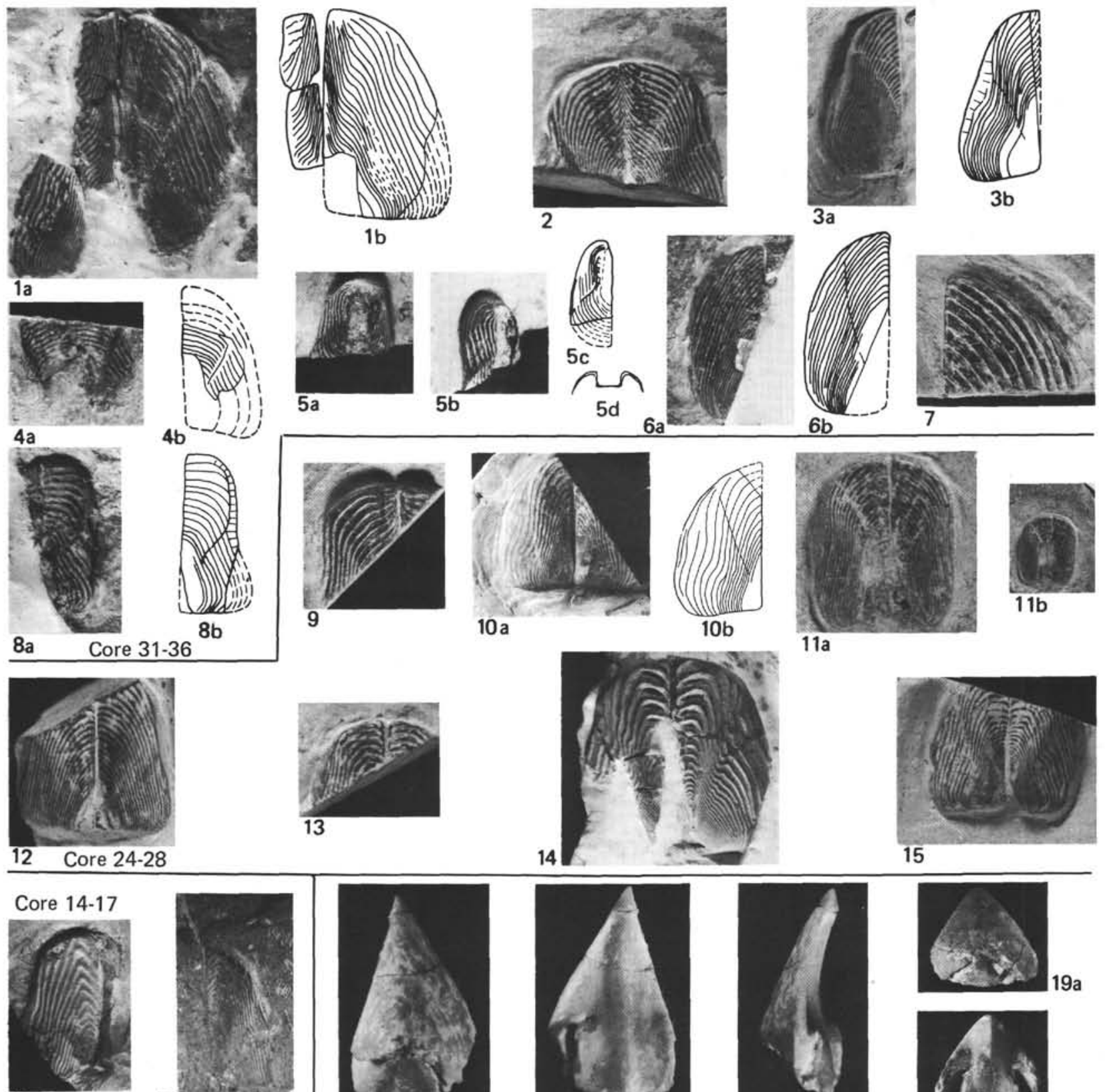

16
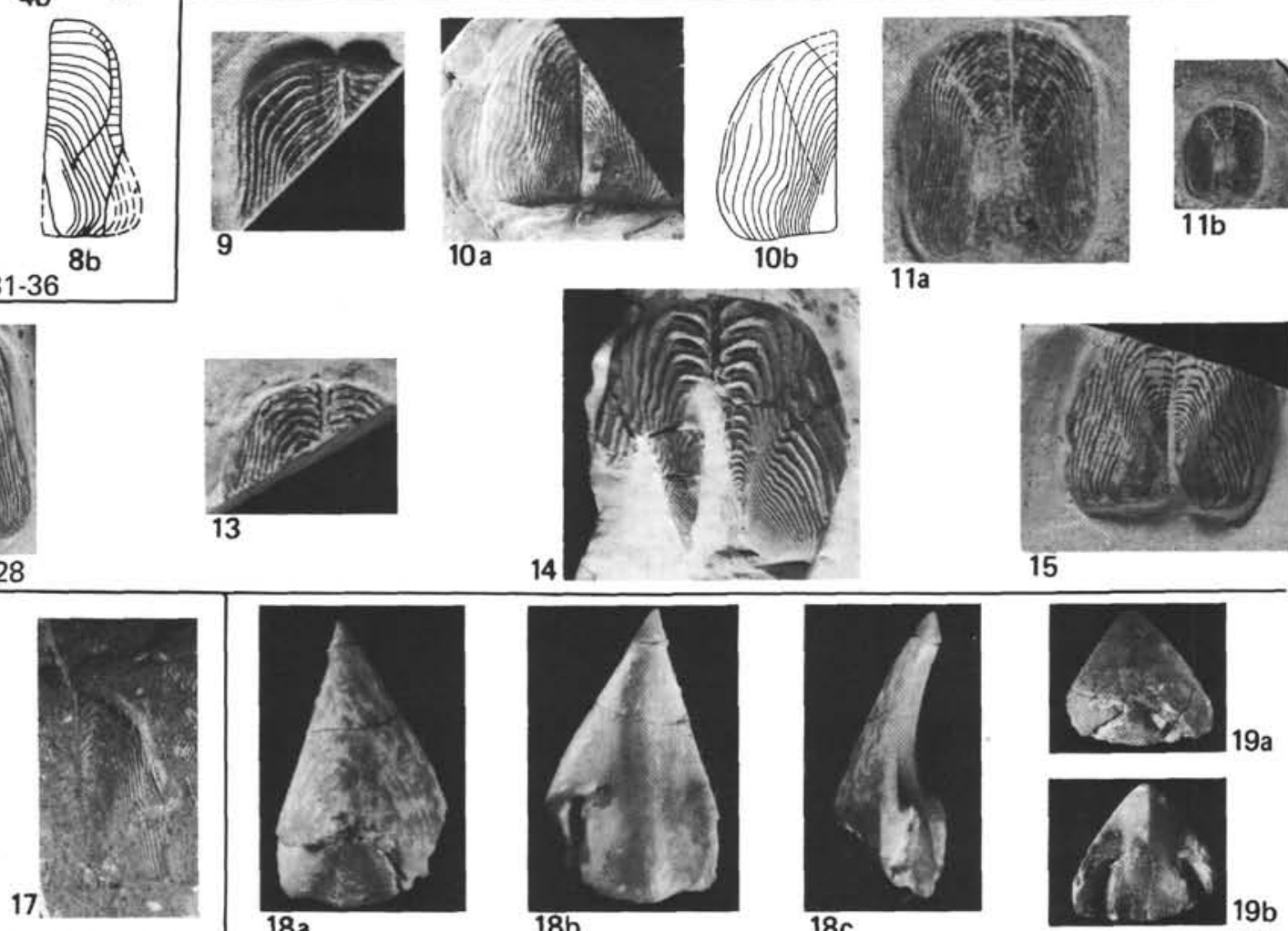

$11 \mathrm{~b}$
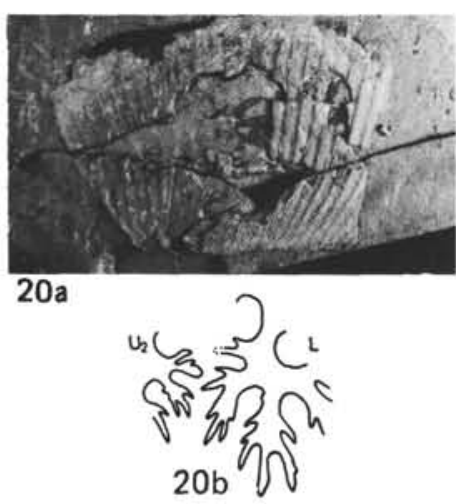
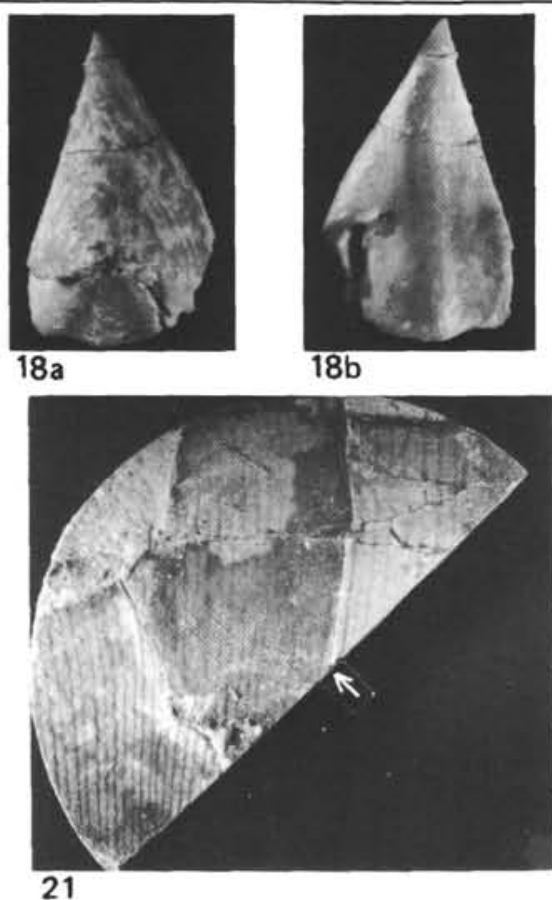

$18 \mathrm{c}$
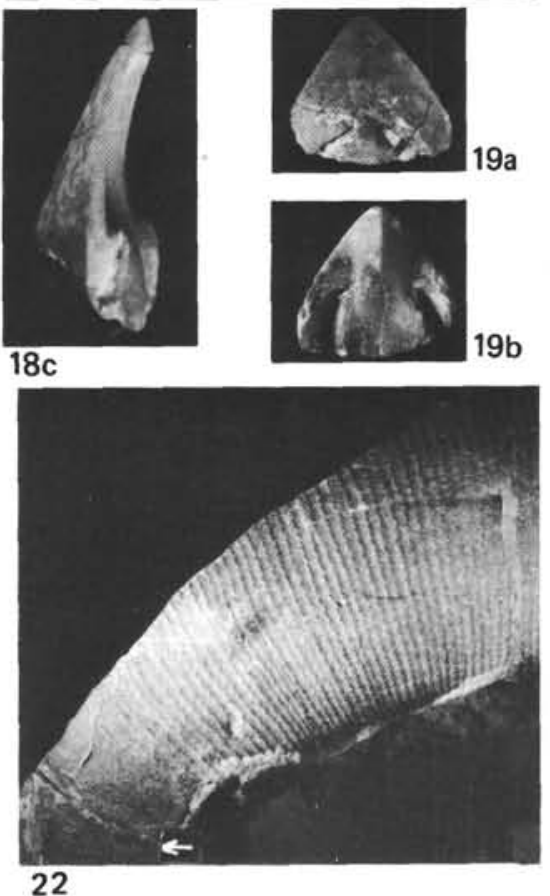